\title{
13. GEOTHERMAL MEASUREMENTS ON DSDP LEG 26
}

\author{
R. D. Hyndman, Dalhousie University, Halifax, Nova Scotia, Canada \\ and \\ A. J. Erickson' and R. P. Von Herzen, Woods Hole Oceanographic Institution, Woods Hole, Massachusetts
}

\begin{abstract}
Nine downhole in situ temperature estimates were obtained from five holes on DSDP Leg 26. The heat-flow determinations were reliable at four sites. Closely spaced temperature measurements in two holes provided a good confirmation of the reproducibility of the measured temperatures using the downhole recorder. A number of temperature-versus-time records clearly shows the decay of penetration heating of the probe, permitting theoretical extrapolation of in situ temperature to equilibrium. Heat flux is nearly constant with depth at the two sites, each with four temperature points (including sea-bottom-water temperature). There is close general agreement between the Leg 26 sites and the results of the nearest shallow ocean probe. The Leg 26 sites show no systematic variation with age.
\end{abstract}

\section{INTRODUCTION}

Measurements of the rate of flow of heat from the sea floor have made an important contribution to our understanding of ocean-floor structure and processes since the first values were reported in 1952 (Revelle and Maxwell, 1952). Several thousand reliable measurements have now been made. Important results have been (Langseth and Von Herzen, 1971; Bullard, 1963): (1) The equality of average measured oceanic and continental heat flows which requires quite different mantle composition or structure beneath oceans and continents. (2) The high values over ocean ridges and low values associated with trenches which support the platetectonic hypothesis. An understanding of the thermal regime of spreading lithospheric plates also explains the topographic elevation and low Bouguer gravity anomaly associated with ridges (Sclater and Francheteau, 1970; McKenzie, 1967) and the Benioff zone behind trenches (McKenzie, 1969). (3) Evidence for hydrothermal processes at ridge crests and endothermic metamorphic reactions on he flanks of ridges (Lister, 1972; Hyndman and Rankin, 1972; Anderson, 1972).

Heat flux is obtained from the product of the thermal gradient and thermal conductivity at shallow depth in the earth. The majority of oceanic heat-flow measurements has been made by measuring the vertical temperature gradient with sensors along a 2- to 10 -meter probe dropped into the soft bottom sediments and by measuring the thermal conductivity on sediment core samples from the same location. These measurements show a large amount of variability reflecting significant environmental sources of error such as bottom-water-

'Now at Geology Department, University of Georgia, Athens, Georgia. temperature variations, heat absorbed by sediments, refraction of heat by small-scale bottom topography, and convective transport of heat (Von Herzen and Uyeda, 1963). A check of heat-flow values measured using the short-probe technique against values determined from deeper measurements was first provided by the preliminary Mohole site. Heat-flow values computed from temperature and thermal conductivity measured to a depth of 150 meters beneath the sea floor compared closely to values determined from standard techniques (Von Herzen and Maxwell, 1964).

The Deep Sea Drilling Project provides an opportunity to measure heat flow in ocean-floor holes several hundred meters deep and, thus, to obtain highly accurate measurements relatively free from the nearsurface disturbances to which short-probe measurements are subject. It also should be possible to determine the existence of variations in heat flux with depth indicative of long-term bottom-water temperature variations such as may have been associated with the Pleistocene glaciations. Including Leg 27 , successful temperature measurements now have been made in about 23 holes. About half of these give reliable heat-flow values. The results are in close agreement with nearby oceanprobe measurements and provide further confirmation of the validity of the shallow-probe values. The reliable measurements exhibit nearly linear temperature-depth profiles, but the accuracy and number of temperatures in single drill holes have not been sufficient to outline the small changes in heat flux with depth that would result, for example, from Pleistocene bottom-watertemperature changes.

Thermal conductivity is an important physical property of sediments. Its relatiohship to composition and other physical properties is needed to facilitate conductivity estimates required for the downward extrapolation of temperatures from near-surface heat-flow measurements. The Deep Sea Drilling Project has now 
provided an extensive survey of the thermal conductivity of ocean-floor sediments.

This report describes temperature measurements at five sites and thermal conductivity in cores from eight sites in the southern Indian Ocean (Figure 1).

\section{THERMAL CONDUCTIVITY DATA}

\section{Sediments}

Thermal-conductivity measurements were made aboard Glomar Challenger on the sediment cores recovered from the drill holes using the needle-probe method described by Von Herzen and Maxwell (1959). This method measures the temperature increase in the sediment as a function of time due to heat released within the sediment from a long, thin-walled hypodermic needle containing a heating element and a thermistor. The temperature increase is recorded in analog form and digitized, and a curve of the form $T=A+B t+C \ln (t)$ is fitted to the temperature $(T)$ versus time $(t)$ data using a nonlinear regression program. Reduction of the data in this manner permits the removal of nearly linear temperature changes arising from the difference in ambient temperature between the sediment core and the laboratory.
The thermal conductivity value $(K)$ determined in this way is further corrected for pressure and temperature conditions below the sea floor using Equation 1, which is based upon correction factors presented by Ratcliffe (1960) and modified for use in DSDP drill holes.

$$
K^{1}=K\left[1+\frac{W+\rho \mathrm{H}}{1829 \times 100}+\frac{T_{w}+H \frac{d T}{d z}-T_{l a b}}{4 \times 100}\right]
$$

$K^{1} \quad=$ thermal conductivity corrected for temperature and pressure

$W \quad=$ water depth $(\mathrm{m})$

$\rho \quad=$ mean sediment density $\left(\mathrm{g} / \mathrm{cm}^{3}\right)$

$H \quad=$ drill hole depth (m)

$T_{w} \quad=$ bottom-water temperature $\left({ }^{\circ} \mathrm{C}\right)$

$d T / d z=$ mean geothermal gradient $\left({ }^{\circ} \mathrm{C} / \mathrm{m}\right)$

$T_{\text {lab }}=$ mean measurement temperature $\left({ }^{\circ} \mathrm{C}\right)$

The values of these parameters used for each site for data reduction are presented in Table 1 . Where possible, the geothermal gradient and bottom-water temperature have been determined using down-hole data and the density from measurements on cores.

If not measured at the site, bottom-water temperatures were obtained from hydrographic data and

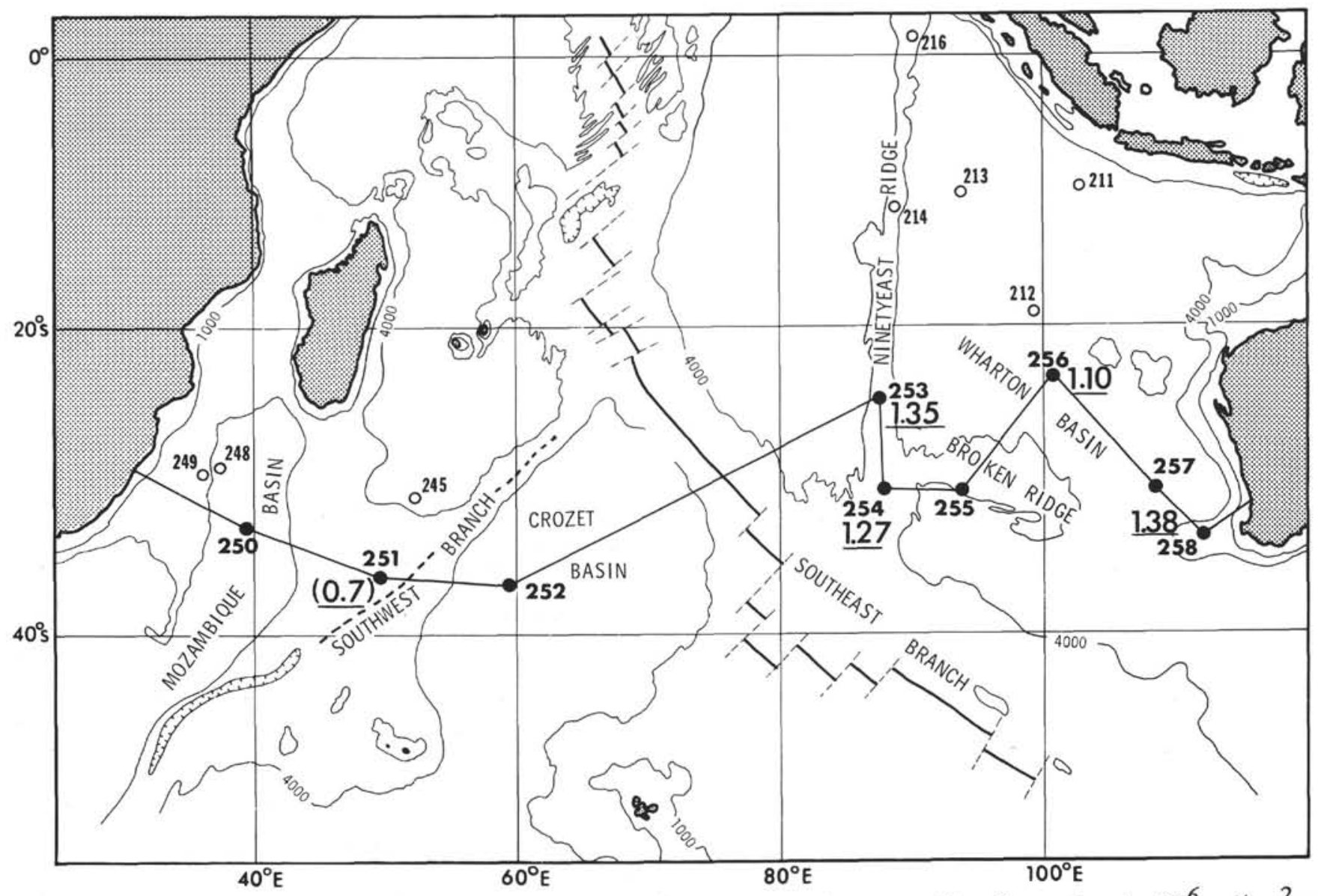

Figure 1. Locations. of Leg 26 heat-flow measurements. Depth contours are in meters. Heat flow values in $10^{-6} \mathrm{cal} / \mathrm{cm}^{2} \mathrm{sec}$ are underlined. 
TABLE 1

Site Parameters Used for Environmental Corrections

\begin{tabular}{lcccc}
\hline Hole & $\begin{array}{c}\text { Water } \\
\text { Depth } \\
(\mathrm{m})\end{array}$ & $\begin{array}{c}\text { Bottom Water } \\
\text { Temperature } \\
(\circ \mathrm{C})\end{array}$ & $\begin{array}{c}\text { Geothermal } \\
\text { Gradient } \\
(\circ \mathrm{C} / \mathrm{m})\end{array}$ & $\begin{array}{c}\text { Sediment } \\
\text { Density } \\
\left(\mathrm{g} / \mathrm{cm}^{3}\right)\end{array}$ \\
\hline 250 & 5119 & $(2.0)$ & $(0.060)$ & 1.75 \\
$250 \mathrm{~A}$ & & 1.53 & 0.025 & 1.70 \\
251 & 3489 & & & \\
$251 \mathrm{~A}$ & & 2.50 & 0.045 & 1.75 \\
253 & 1962 & 3.70 & 0.045 & 1.70 \\
254 & 1253 & 1.14 & 0.054 & 1.40 \\
256 & 5361 & 1.06 & 0.070 & 1.50 \\
257 & 5278 & $(3.0)$ & $(0.060)$ & 1.63 \\
258 & 2793 & & & \\
\hline
\end{tabular}

Note: Estimated parameters in parentheses.

gradients from regional heat-flow values. These corrections are only a few percent, and the uncertainty from this source is usually less than that from the measurement. Parameters which are estimated are enclosed in parentheses in Table 1.

The results of the thermal-conductivity measurements made during Leg 26 are listed in Table 2. Conductivity data from all sites have been combined in Figure 2, with two interesting results-a bimodal grouping of the data and a generally linear increase in conductivity with depth.

There is definite bimodal grouping for data from Sites 250, 250A, 256, and 257 (Group A) and from Sites 251, 251A, 253, 254, and 258 (Group B). With the exception of only one data point, no data from Group A occurs within the envelope defined by the dotted line around

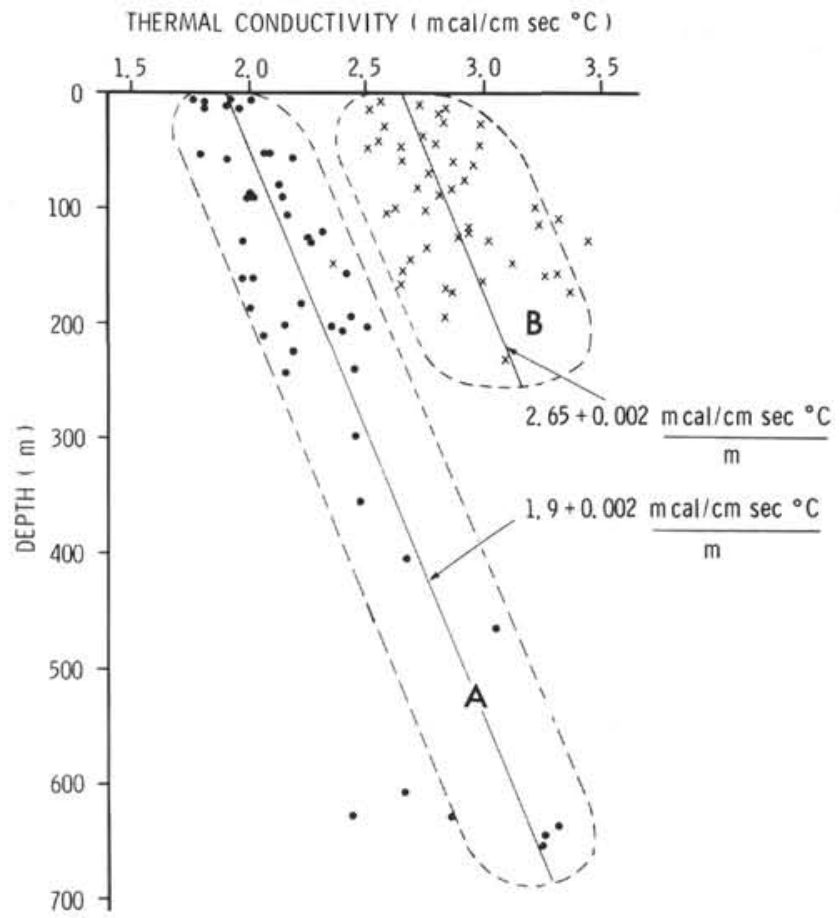

Figure 2. Thermal conductivity compilation for Leg 26.

TABLE 2

Thermal-Conductivity Data, Leg 26

\begin{tabular}{lccc}
\hline $\begin{array}{c}\text { Sample } \\
\text { (Interval in cm) }\end{array}$ & $\begin{array}{c}\text { Sub- } \\
\text { bottom } \\
\text { Depth } \\
\text { (m) }\end{array}$ & $\begin{array}{c}\text { Thermal } \\
\text { Conductivity } \\
\text { Measured }\end{array}$ & $\begin{array}{c}\text { (mcal/cm sec }{ }^{\circ} \mathrm{C} \text { ) } \\
\text { Corrected }\end{array}$ \\
\hline 250-1-4, 75 & 5 & 1.95 & 1.92 \\
$250-2-4,60$ & 14 & 1.85 & 1.81 \\
$250-3-2,45$ & 57 & 1.93 & 1.91 \\
250A-1-4, 75 & 60 & 2.22 & 2.19 \\
$250 \mathrm{~A}-3-5,75$ & 80 & 2.14 & 2.13 \\
$250 \mathrm{~A}-4-6,75$ & 120 & 2.31 & 2.31 \\
$250 \mathrm{~A}-5-5,50$ & 156 & 2.41 & 2.42 \\
$250 \mathrm{~A}-6-4,50$ & 193 & 2.22 & 2.24 \\
$250 \mathrm{~A}-7-5,75$ & 242 & 2.14 & 2.15 \\
$250 \mathrm{~A}-8-5,50$ & 299 & 2.42 & 2.44 \\
$250 \mathrm{~A}-9-3,55$ & 353 & 2.47 & 2.47 \\
$250 \mathrm{~A}-10-2-75$ & 408 & 2.55 & 2.65 \\
$250 \mathrm{~A}-11-2,75$ & 465 & 2.88 & 3.03 \\
$250 \mathrm{~A}-14-2,85$ & 608 & 2.47 & 2.65 \\
$250 \mathrm{~A}-15-4,17$ & 629 & 2.26 & 2.43 \\
$250 \mathrm{~A}-15-4,80$ & 630 & 2.64 & 2.85 \\
$250 \mathrm{~A}-16-2,97$ & 639 & 3.05 & 3.29 \\
$250 \mathrm{~A}-17-2,63$ & 645 & 3.00 & 3.24 \\
250A-18-2-50 & 655 & 2.99 & 3.23
\end{tabular}

Harmonic mean, Site $250=2.38 \pm 0.15$.

$\begin{array}{lrrr}251-3-3,80 & 15 & 2.58 & 2.52 \\ 251-4-6,72 & 29 & 3.06 & 2.98 \\ 251-4-6,100 & 30 & 2.65 & 2.58 \\ 251-5-6,50 & 39 & 2.81 & 2.74 \\ 251-6-6,50 & 48 & 2.72 & 2.65 \\ 251-7-6,51 & 58 & 2.72 & 2.65 \\ 251-8-5,50 & 66 & 3.05 & 2.95 \\ 251-10-5,75 & 82 & 2.81 & 2.72 \\ 251 \mathrm{~A}-4-6,75 & 115 & 3.30 & 3.23 \\ 251 \mathrm{~A}-5-6,70 & 124 & 2.99 & 2.93 \\ 251 \mathrm{~A}-6-6,79 & 134 & 2.80 & 2.75 \\ 251 \mathrm{~A}-7-6,70 & 143 & 2.73 & 2.68 \\ 251 \mathrm{~A}-9-6,49 & 162 & 3.06 & 3.00 \\ 251 \mathrm{~A}-10-6,50 & 172 & 2.92 & 2.87 \\ 251 \mathrm{~A}-11-3,50 & 196 & 2.87 & 2.83 \\ 251 \mathrm{~A}-12-6,50 & 229 & 3.15 & 3.08\end{array}$

Harmonic mean, Site $251=2.79 \pm 0.18$.

$\begin{array}{lrrr}253-3-5,59 & 25 & 2.93 & 2.83 \\ 253-5-5,63 & 44 & 2.87 & 2.79 \\ 253-7-5,82 & 63 & 3.04 & 2.95 \\ 253-9-5,73 & 82 & 2.94 & 2.86 \\ 253-11-5,69 & 101 & 3.28 & 3.21 \\ 253-12-4,70 & 109 & 3.41 & 3.31 \\ 253-13-4,70 & 119 & 3.00 & 2.93 \\ 253-14-4,70 & 128 & 3.51 & 3.44 \\ 253-16-5,80 & 149 & 3.18 & 3.12\end{array}$

Harmonic mean, Site $253=3.20 \pm 0.22$.

$\begin{array}{lrrl}254-2-4,50 & 11 & 2.81 & 2.71 \\ 254-3-4,50 & 20 & 2.90 & 2.80 \\ 254-5-5,50 & 41 & 2.64 & 2.55 \\ 254-6-5,50 & 50 & 2.67 & 2.59 \\ 254-7-5,50 & 60 & 2.96 & 2.87 \\ 254-8-5,50 & 69 & 2.84 & 2.76 \\ 254-9-3,50 & 76 & 2.99 & 2.91 \\ 254-10-5,50 & 88 & 2.89 & 2.81 \\ 254-11-6,50 & 99 & 2.71 & 2.63 \\ 254-11-1,50 & 101 & 2.82 & 2.75 \\ 254-12-4,50 & 106 & 2.67 & 2.58 \\ 254-18-2,50 & 150 & 2.40 & 2.35 \\ 254-18-6,50 & 156 & 2.71 & 2.65 \\ 254-19-2,40 & 159 & 3.39 & 3.31 \\ 254-19-2,50 & 160 & 3.35 & 3.26 \\ 254-19-6,70 & 166 & 2.70 & 2.65\end{array}$


TABLE 2 - Continued

\begin{tabular}{|c|c|c|c|}
\hline $\begin{array}{c}\text { Sample } \\
\text { (Interval in } \mathrm{cm} \text { ) }\end{array}$ & $\begin{array}{l}\text { Sub- } \\
\text { bottom } \\
\text { Depth } \\
\text { (m) }\end{array}$ & $\begin{array}{c}\text { Thermal } \\
\text { Conductivity } \\
\text { Measured }\end{array}$ & $\begin{array}{c}\left(\mathrm{mcal} / \mathrm{cm} \mathrm{sec}^{\circ} \mathrm{C}\right) \\
\text { Corrected }\end{array}$ \\
\hline $254-20-2.50$ & 169 & 2.92 & 2.84 \\
\hline $254-20-4,105$ & 173 & 3.43 & 3.36 \\
\hline \multicolumn{4}{|c|}{ Harmonic mean, Site $254=2.75 \pm 0.22}$. \\
\hline $\begin{array}{l}256-1-5,50 \\
256-3-5,51 \\
256-4-2,50 \\
256-4-5,50 \\
256-5-2,102 \\
256-5-4,75 \\
256-6-2,75 \\
256-6-5,75 \\
256-7-3,73 \\
256-8-5,80\end{array}$ & $\begin{array}{r}7 \\
54 \\
88 \\
92 \\
126 \\
129 \\
183 \\
187 \\
213 \\
244\end{array}$ & $\begin{array}{l}2.05 \\
1.83 \\
2.05 \\
2.18 \\
2.27 \\
2.00 \\
2.22 \\
1.99 \\
2.07 \\
2.18\end{array}$ & $\begin{array}{l}2.00 \\
1.79 \\
2.03 \\
2.14 \\
2.25 \\
1.99 \\
2.22 \\
1.99 \\
2.06 \\
2.19\end{array}$ \\
\hline \multicolumn{4}{|c|}{ Harmonic mean, Site $256=2.04 \pm 0.13$} \\
\hline $\begin{array}{l}257-1-5,50 \\
257-1-6,50 \\
257-2-3,50 \\
257-2-4,50 \\
257-3-2,60 \\
257-3-3,50 \\
257-4-4,50 \\
257-4-4,97 \\
257-5-2,50 \\
257-5-3,50 \\
257-6-1,70 \\
257-6-1,100 \\
257-7-2,50 \\
257-7-2,100 \\
257-7-4,50 \\
257-7-5,75 \\
257-8-2,50\end{array}$ & $\begin{array}{r}7 \\
8 \\
12 \\
15 \\
50 \\
51 \\
91 \\
91 \\
126 \\
130 \\
162 \\
163 \\
201 \\
202 \\
204 \\
206 \\
240\end{array}$ & $\begin{array}{l}1.80 \\
1.87 \\
1.95 \\
2.00 \\
2.12 \\
2.10 \\
2.04 \\
2.00 \\
2.16 \\
2.26 \\
2.00 \\
1.95 \\
2.12 \\
2.32 \\
2.22 \\
2.35 \\
2.39\end{array}$ & $\begin{array}{l}1.76 \\
1.82 \\
1.92 \\
1.96 \\
2.09 \\
2.07 \\
2.03 \\
1.99 \\
2.16 \\
2.27 \\
2.01 \\
1.97 \\
2.16 \\
2.36 \\
2.25 \\
2.40 \\
2.44 \\
\end{array}$ \\
\hline \multicolumn{4}{|c|}{ Harmonic mean, Site $257=2.06 \pm 0.17$. } \\
\hline $\begin{array}{l}258-1-6,50 \\
258-2-3,50 \\
258-3-6,50 \\
258-5-3,50 \\
258-6-5,50\end{array}$ & $\begin{array}{r}8 \\
13 \\
56 \\
127 \\
130\end{array}$ & $\begin{array}{l}2.65 \\
2.91 \\
3.05 \\
2.92 \\
3.04\end{array}$ & $\begin{array}{l}2.56 \\
2.83 \\
2.97 \\
2.89 \\
3.01\end{array}$ \\
\hline \multicolumn{4}{|c|}{ Harmonic mean, Site $258=2.81 \pm 0.16$} \\
\hline
\end{tabular}

Group B data, and vice versa. The mean conductivity within any depth interval of Group A is about 0.7 $\mathrm{mcal} / \mathrm{cm}$ sec ${ }^{\circ} \mathrm{C}$, less than that within the corresponding interval of Group B. The difference between groups arises from differences in the bulk composition, and to a lesser extent, in the bulk texture. Group A sites are all deeper than 5000 meters and Group B are shallower than 3500 meters, so they represent, respectively, sites below and above the carbonatecompensation depth. Cores in Group A are predominantly detrital clay and nannoplankton and coccolith oozes, whereas sediments in Group B are primarily carbonates.

The second feature made clear in the compilation (Figure 2) is the roughly linear increase in conductivity with depth (about $0.002 \mathrm{mcal} / \mathrm{cm} \mathrm{sec}{ }^{\circ} \mathrm{C}$ per m) established from the data of Group A, and to a lesser extent apparent in Group B. The results are consistent with the compaction and reduction of porosity with depth of clays and oozes (e.g., Hamilton, 1959) and the increase in conductivity with decreasing porosity (Ratcliffe, 1960). The increase in thermal conductivity with depth is as large as $50 \%$ in the deeper holes (Figure 2) and must be taken into account both in the interpretation of heatflow data and in downward extrapolations of temperature from shallow temperature data. The few values at the bottom of Group A that do not fit the general trend are atypical sediments from just above the basalt.

The harmonic mean thermal conductivity (or arithmetic mean thermal resistivity) of measurements from cores from depths between temperature points was used for heat-flow computation, except where noted, in the results section. In several holes where there were only a few conductivity values, the general relation illustrated in Figure 2 was also used as a check.

\section{Basalts}

The thermal conductivity of six basalt samples from Site 257 was measured using a divided bar instrument of the type described by Birch (1950) but with constanttemperature ends. The samples were discs $25 \mathrm{~mm}$ in diameter and $6 \mathrm{~mm}$ thick. They were water soaked for seven days before measurement. Contact was made with a glycerine and water mix at a pressure of 30 bars. Corrections were applied for contact resistance, lateral heat loss, and small variations in disc diameter. The mean sample temperature was $20^{\circ} \mathrm{C}$. Calibration was with quartz and fused-silica discs using the values of Ratcliffe (1959). The accuracy of the measurements is better than $\pm 5 \%$ (Table 3 ). The conductivities increase slightly with depth. The harmonic or series mean is 3.70 $\pm 0.06 \mathrm{mcal} / \mathrm{cm} \mathrm{sec}{ }^{\circ} \mathrm{C}$. This is similar but slightly lower than the mean of 3.9 found for shallow drilled basalt samples from the Mid-Atlantic Ridge (Hyndman and Jessop, 1971). For the heat flows of 0.7 to 1.4 $\mu \mathrm{cal} / \mathrm{cm}^{2} \mathrm{sec}$ found on Leg 26 , a conductivity of 3.7 implied a vertical temperature gradient in the upper crust of $19-38^{\circ} \mathrm{C} / \mathrm{km}$.

TABLE 3

Basalt Thermal-Conductivity Data, Site 257

\begin{tabular}{lcc}
\hline $\begin{array}{c}\text { Sample } \\
\text { (Interval } \\
\text { in cm) }\end{array}$ & $\begin{array}{c}\text { Depth Into } \\
\text { Basalt }(\mathrm{m})\end{array}$ & $\begin{array}{c}\text { Thermal } \\
\text { Conductivity } \\
\left(\mathrm{mcal} / \mathrm{cm} \mathrm{sec}^{\circ} \mathrm{C}\right)\end{array}$ \\
\hline $11-2,74$ & 3.24 & 3.51 \\
$12-1,130$ & 11.80 & 3.62 \\
$12-3,35$ & 13.85 & 3.55 \\
$13-3,15$ & 23.15 & 3.86 \\
$14-2,95$ & 30.45 & 3.81 \\
$15-1,133$ & 37.33 & 3.89 \\
\hline \multicolumn{3}{c}{ Note: Harmonic mean $=3.70 \pm 0.06$} \\
\multicolumn{2}{c}{$\mathrm{mcal} / \mathrm{cm}$ sec ${ }^{\circ} \mathrm{C}}$.
\end{tabular}

\section{SEDIMENT TEMPERATURES}

\section{Technique}

Sediment temperatures were obtained by forcing a thin probe into the undisturbed sediments below the drill bit at intervals during which drilling was suspended. The temperature of a thermistor in the probe is 
recorded in a self-contained instrument within the core barrel. This technique is used rather than simply logging the completed hole because the thermal disturbance in the hole due to drilling decays very slowly, requiring some weeks before attaining equilibrium.

A new recording package was first used on Leg 26. It was designed and constructed at Woods Hole Oceanographic Institution and is similar to the older instrument described by Erickson (1973), except for having simplified and more reliable electronics and a new taperecording system. The downhole recorder contains the electronics to obtain a digital value of a frequency analog of the thermistor resistance and records this data on a miniature digital tape recorder. The temperaturetime record is obtained onboard using the Glomar Challenger PDP-8 computer. The temperature resolution and the accuracy of relative temperatures are about $\pm 0.01{ }^{\circ} \mathrm{C}$, and the absolute temperatures are accurate to at least $0.1{ }^{\circ} \mathrm{C}$.

The facility for measuring temperature has been designed so that a reading can be taken as part of the normal coring procedure thereby requiring only an additional $15 \mathrm{~min}$. When used in this way the instrument is attached to the bottom of the inside of the core barrel with a release latch, the sensor extending about 1 meter below. The core barrel is dropped or pumped down the drill pipe and seated into the top of the drill bit. The bit assembly is then lowered slowly to force the sensor probe into the undisturbed sediments. The bit is held stationary for about $10 \mathrm{~min}$ to allow for the decay of the heat produced by the probe being forced into the sediment. Then coring is commenced. The extra pressure on the instrument at the initiation of coring is intended to release the latch and force the instrument up to the top of the core barrel on top of the entering core. The release latch had been unreliable on previous legs, and a new ball detent mechanism was tried. This unit locked the instrument into the bottom of the core barrel until the barrel was seated in the bit, solving an earlier problem of premature release on the was down. However, on four lowerings with the release latch, only two short cores were obtained, and the temperatures were all unreliable. They did not show the characteristic penetration decay curve (e.g., Figures 3-7). Apparently the instrument was measuring temperatures in sediments sloughed to the bottom of the hole or was forced into the core barrel before the probe penetrated into the underlying undisturbed sediment.

Reliable temperatures were obtained only with the instrument locked into the bottom of the core barrel, permitting the probe to be forced into undisturbed sediments. These lowerings produced uniform penetration disturbance decay curves that could be extrapolated to equilibrium to give undisturbed temperatures.

Another serious difficulty was the frequent bending of the sensor extenders. It is likely that the extenders were being deflected into contact with the back of the bit by the bottom "flapper" valve used to prevent water backflow. One instrument was lost, apparently because the bent extender became entangled in the bit and pulled the instrument out through the core catchers when the core barrel was retrieved.
The instrument lowering data are summarized in Table 4. Data were obtained on 12 lowerings, of which 8 are useful for heat-flow determinations.

\section{Decay of Penetration Temperature Disturbance}

The temperature-time plots (Figures 3-7, particularly Figure 4) illustrate frictional heating of the probe on penetration and its subsequent decay. When the heating brings the probe above the sediment temperature, the decay is a cooling; and where the heating is insufficient to raise the temperature of the probe above the sediment temperature, the approach to equilibrium is a warming. The recorded temperatures can be extrapolated to equilibrium using the theory of Bullard (1954) or Jaeger (1956). The DSDP sensor has a thermal time constant in the sediment $\left(a^{2} / k\right)$ of about $75 \mathrm{sec}(k$ is the thermal diffusivity of the sediment, and $a$ is the radius of the probe).

Figure 8 shows the extrapolation of the recorded temperatures to equilibrium. The function $F$ (Bullard, 1954 ) approaches 0 as time $t$ goes to infinity. For "long" times (greater than about $5 \mathrm{~min}$ for this probe), $F$ is proportional to $l / t$, and approximate equilibrium temperatures may be estimated by plotting temperature versus $l / t$ and extrapolating to $l / t=0$ or $t=\infty$. This simple extrapolation is convenient for shipboard evaluation of the data. If the extrapolation plots are not linear, the probe probably has not measured undisturbed sediment temperatures (e.g., Site 251, $87.5 \mathrm{~m}$; Site 254, 119.5 $\mathrm{m}$; Site 257, 171.0 m). On eight lowerings linear plots of temperature versus $F$ were obtained for at least a portion of the record, although none showed completely undisturbed records after penetration of the probe. Only deviations of $\pm 0.02^{\circ} \mathrm{C}$ from linearity can be ascribed to recording uncertainty, larger disturbances must represent movement of the probe. Six of the lowerings showed an approach to equilibrium by cooling from a large initial penetration heating pulse, and most had continuous decay curves for the length of the recording. On one of these (Site 256, $161.5 \mathrm{~m}$ ) a later approach to equilibrium by warming was used for extrapolation. The remaining two lowerings showed no large penetration heating and approached equilibrium by warming. In both of these cases, the measured temperatures decreased relative to the theoretical decay curves within 2 min of penetration. The small penetration heating and the fact that the disturbance quickly reached the probe

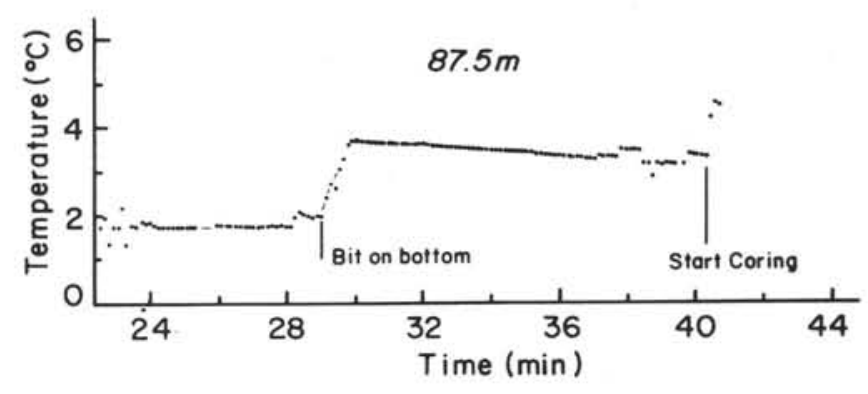

Figure 3. Temperature versus time records from downhole instrument, Site 251. 
TABLE 4

Summary of Leg 26 Temperature Measurements

\begin{tabular}{|c|c|c|c|c|c|}
\hline Measurement & $\begin{array}{l}\text { Depth } \\
\text { in Hole } \\
\text { (m) }\end{array}$ & $\begin{array}{c}\text { Data } \\
\text { Recorded? }\end{array}$ & $\begin{array}{l}\text { Data OK for } \\
\text { Heat Flow? }\end{array}$ & $\begin{array}{l}\text { Latch } \\
\text { Mode }\end{array}$ & Comments \\
\hline \multicolumn{6}{|l|}{ Hole 251} \\
\hline 1 & 87.5 & Yes & No & Ball & $\begin{array}{l}\text { Probably released prematurely, small penetration } \\
\text { heating pulse }\end{array}$ \\
\hline \multicolumn{6}{|l|}{ Hole $251 \mathrm{~A}$} \\
\hline 2 & 258.5 & Yes & No & Ball & Data lost in readout; probe tip bent $20^{\circ}$ \\
\hline \multicolumn{6}{|l|}{ Site 253} \\
\hline $\begin{array}{l}3 \\
4 \\
5\end{array}$ & $\begin{array}{l}104 \\
123 \\
142\end{array}$ & $\begin{array}{l}\text { Yes } \\
\text { Yes } \\
\text { Yes }\end{array}$ & $\begin{array}{l}\text { Yes } \\
\text { Yes } \\
\text { Yes }\end{array}$ & $\begin{array}{l}\text { Locked } \\
\text { Locked } \\
\text { Locked }\end{array}$ & $\begin{array}{l}\text { Disturbed after } 3 \mathrm{~min} \text {, but well-defined decay } \\
\text { curve }\end{array}$ \\
\hline \multicolumn{6}{|l|}{ Site 254} \\
\hline 6 & 119.5 & Yes & No & Ball & $\begin{array}{l}\text { Premature latch release, small penetration heating } \\
\text { pulse }\end{array}$ \\
\hline 7 & 137 & Yes & Yes & Locked & \\
\hline 8 & 148 & Yes & Yes & Locked & Warming approach to equilibrium \\
\hline 9 & 176.5 & Yes & Yes & Locked & Only $1 \frac{1 / 2}{\mathrm{~min}}$ of undisturbed probe decay \\
\hline \multicolumn{6}{|l|}{ Site 256} \\
\hline 10 & 161.5 & Yes & Yes & Ball & $\begin{array}{l}\text { Soft sediments, disturbed record, temp. estimate } \\
\text { from second bit lowering. }\end{array}$ \\
\hline 11 & 218.5 & $?$ & No & Ball & Instrument lost. \\
\hline \multicolumn{6}{|l|}{ Site 257} \\
\hline $\begin{array}{l}12 \\
13 \\
14\end{array}$ & $\begin{array}{l}133 \\
171 \\
209\end{array}$ & $\begin{array}{l}\text { Yes } \\
\text { Yes } \\
\text { No }\end{array}$ & $\begin{array}{l}\text { Yes } \\
\text { No } \\
\text { No }\end{array}$ & $\begin{array}{l}\text { Locked } \\
\text { Locked } \\
\text { Locked }\end{array}$ & $\begin{array}{l}\text { Warming approach to equilibrium } \\
\text { Probe tip bent } 90^{\circ} \text {, small penetration heating pulse } \\
\text { Extender broken, connector to battery pack pulled } \\
\text { apart shortly after turn on. }\end{array}$ \\
\hline
\end{tabular}

both indicate that the probe penetrated disturbed sediment or only a short distance into the undisturbed sediments.

\section{TEMPERATURE AND HEAT-FLOW RESULTS}

The estimated in situ temperatures for 11 lowerings of the sediment temperature probe and the corresponding conductivity-depth profiles are shown in Figures 9-13. The holes are discussed individually in the section below. The error estimates given are subjective. The heat-flow data for each lowering are summarized in Table 5.

\section{Site 251}

Bottom-hole temperatures were recorded at 87.5 meters in Hole 251 and 258.5 meters in Hole 251A, both measurements using the ball detent release latch. The data from the second lowering were lost in readout. The temperature-time curve (Figures 3-7) for the first measurement showed no sharp temperature increase associated with penetration heating and does not decrease or increase according to the theoretical approach to equilibrium. The latch probably released prematurely and allowed the probe to be forced into the core barrel. Thus, the recorded temperature is probably that of sediment sloughed to the hole bottom. The maximum recorded temperature of $3.70^{\circ} \mathrm{C}$ is probably much lower than the in situ temperature. The bottom-water temperature recorded is $1.53^{\circ} \mathrm{C}$ giving a lower limit to the gradient of $0.025^{\circ} \mathrm{C} / \mathrm{m}$. The harmonic mean thermal conductivity of eight core samples from 15 to 82 meters in depth is $2.71 \pm 0.16 \mathrm{mcal} / \mathrm{cmsec}^{\circ} \mathrm{C}$, giving a minimum heat flow of $0.7 \mu \mathrm{cal} / \mathrm{cm}^{2} \mathrm{sec}$. The true value is likely to be higher.

\section{Site 253}

Three excellent temperature measurements were made at Site 253 at 104, 123, and 142 meters. The probe was locked into the core barrel for each lowering. The soft ooze above 100 meters would not support the bit assembly, and below 150 meters volcanic ash was encountered that was too hard for penetration of the probe. There was a sharp increase in temperature associated with the probe penetration in each case, with subsequent cooling toward equilibrium. There is an obvious disturbance $2 \mathrm{~min}$ after penetration at 142 meters, but the record is then undisturbed for another $6 \mathrm{~min}$. The bit likely was lifted off the bottom, pulling out the probe and then again lowered into the bottom. Both parts of the curve can be used for extrapolation, giving essentially the same equilibrium temperature. Small disturbances are also seen after $5 \mathrm{~min}$ at both 104 and 125 meters (Figures 2-7). Extrapolation errors should be less than $\pm 0.03^{\circ} \mathrm{C}$ and temperature differences between values accurate to about $3 \%$ or $4 \%$. The equilibrium temperatures are $7.51 \pm 0.03^{\circ} \mathrm{C}$ at 104 meters, 8.29 $\pm 0.03^{\circ} \mathrm{C}$ at 123 meters, and $9.07 \pm 0.02^{\circ} \mathrm{C}$ at 142 meters. Relative depths are known to 0.5 meters or about $3 \%$ of 

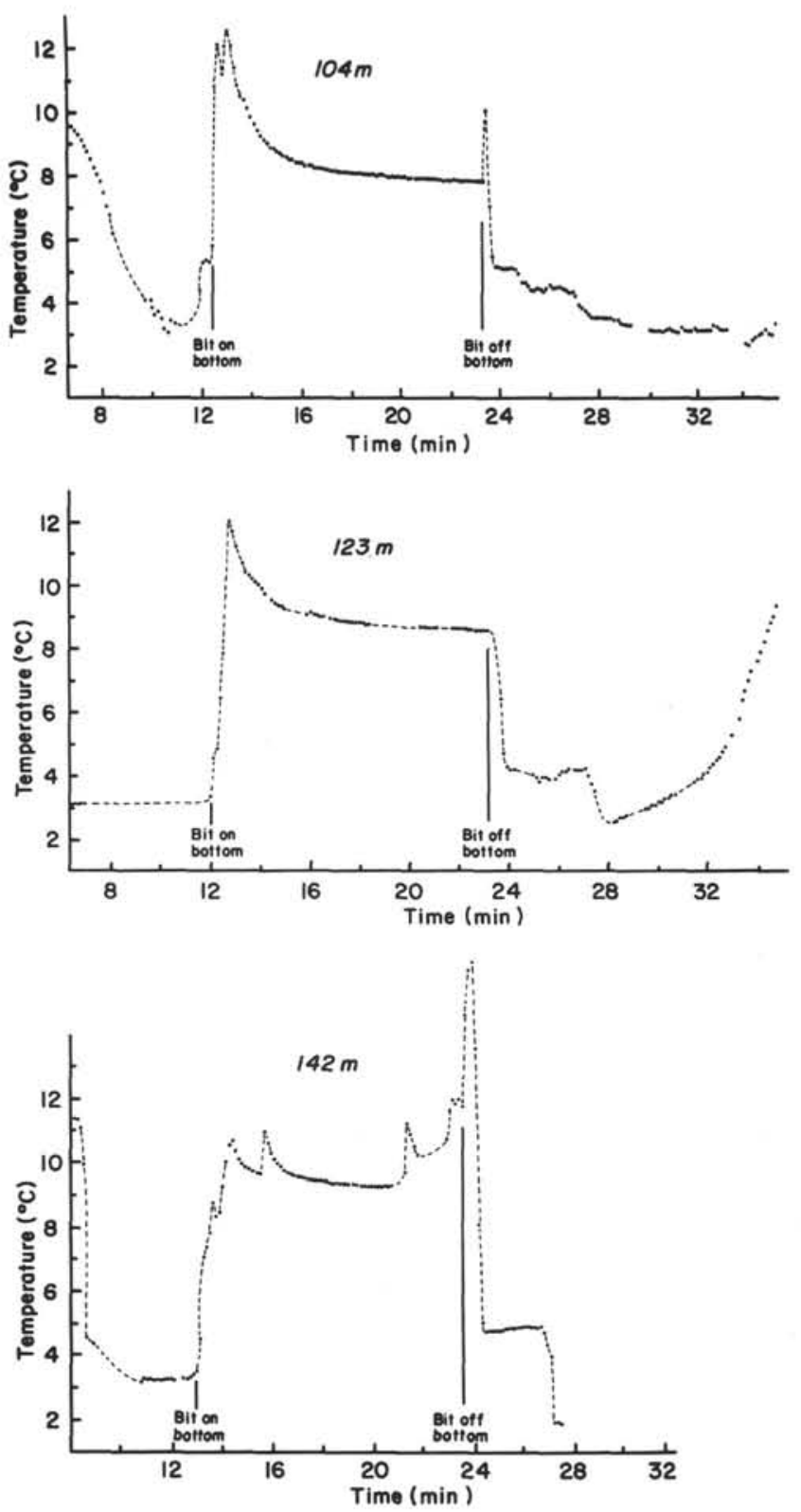

Figure 4. Temperature versus time records from downhole instrument, Site 253.

the interval between values. The gradients between measurements are thus accurate to within $5 \%$ to $7 \%$. The gradients are equal to $0.0411^{\circ} \mathrm{C} / \mathrm{m}$ both between 104 and 123 meters and between 123 and 142 meters depth.

These three temperatures are probably the most reliable and accurate yet obtained on the DSDP program. The linear gradient over such closely spaced depths provides an excellent confirmation of the technique. Measurements have never been repeated at one depth, but these three close values give an almost equally good check on the reproducibility of the measurements.

The bottom-water temperature was not well recorded, but is close to $2.50^{\circ} \mathrm{C}$ which is in agreement with hydrographic data from Wyrtki (1971) giving a gradient from the surface to 104 meters of $0.0482^{\circ} \mathrm{C} / \mathrm{m}$.
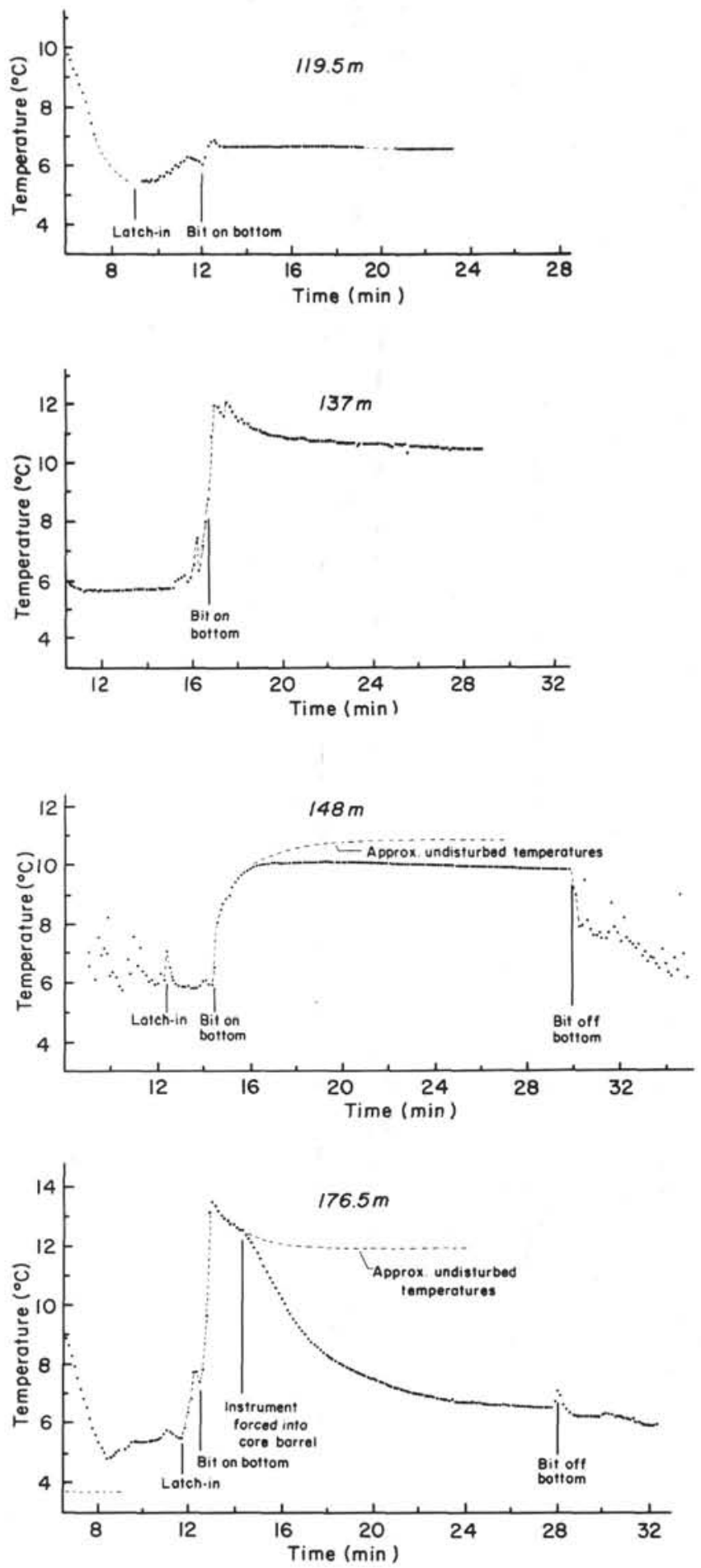

Figure 5. Temperature versus time records from downhole instrument, Site 254.

Only eight thermal conductivities were measured in this hole from 25 to 149 meters depth and only three in the interval between the temperature measurements so interval mean conductivities are poorly determined. However, they are also in general agreement with the general relation of Figure 2. The harmonic mean of five values in and near the temperature interval (101-149 m 


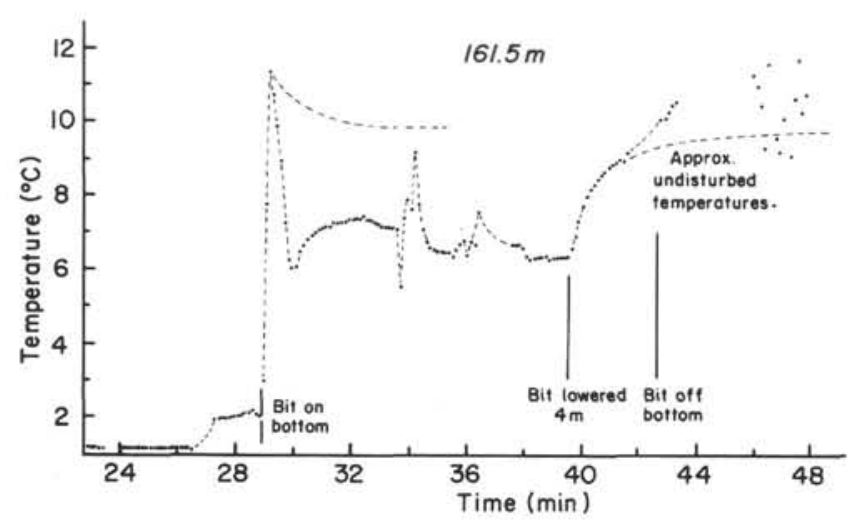

Figure 6. Temperature versus time records from downhole instrument, Site 256.
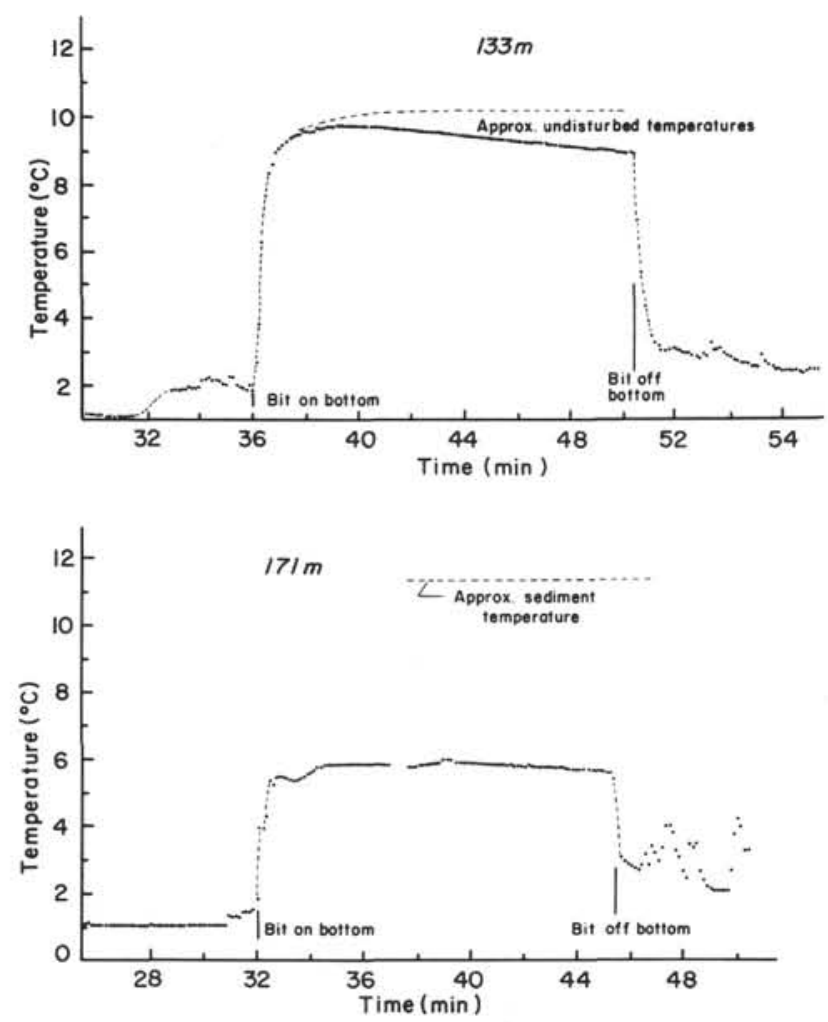

Figure 7. Temperature versus time records from downhole instrument, Site 257.

rather than just $104-142 \mathrm{~m}$ ) is $3.21 \pm 0.19 \mathrm{mcal} / \mathrm{cm} \mathrm{sec}$ ${ }^{\circ} \mathrm{C}$ for a heat flow of $1.32 \pm 0.10 \mu \mathrm{cal} / \mathrm{cm}^{2} \mathrm{sec}$. The mean conductivity of four values between 25 and 82 meters is $2.85 \pm 0.07 \mathrm{mcal} / \mathrm{cmsec}^{\circ} \mathrm{C}$, giving a heat-flow estimate from the surface to 104 meters of $1.37 \pm 0.08$ $\mu \mathrm{cal} / \mathrm{cm}^{2} \mathrm{sec}$. This value is $4 \%$ higher than that between 104 and 142 meters which is in the range of uncertainty. We estimate the best value of heat flow at this site to be $1.35 \pm 0.07 \mu \mathrm{cal} / \mathrm{cm}^{2} \mathrm{sec}$.

\section{Site 254}

Bottom-hole temperatures were measured at four depths at Site 254, at 119.5, 137, 148, and 176.5 meters. The first lowering was with the release latch and subsequent coring. There was only a small temperature increase on penetration and no characteristic decay curve, indicating that the latch released without the probe penetrating undisturbed sediment. A temperature of $6.5^{\circ} \mathrm{C}$ was recorded from penetration until the instrument was on deck. The three other lowerings were with the instrument locked into the core barrel. All of them recorded temperatures in undisturbed sediment, but there were disturbances arising from movement of the probe. The hole penetrated carbonate sand which jammed the bumper subs so that ship motion was transferred directly to the bit. The second lowering (137 $\mathrm{m})$ recorded a smooth decay curve after a sharp penetration pulse, except for several small disturbances. The decay of the disturbances is superimposed on the main curve, but, because of their small initial amplitude they quickly become negligible. The equilibrium temperature is $10.33 \pm 0.03^{\circ} \mathrm{C}$. The third lowering $(148 \mathrm{~m})$ resulted in only a small penetration heating so that the approach to equilibrium was a warming. In common with the other records of this type, there is a divergence from the theoretical curve after $2 \mathrm{~min}$. However, a reliable in situ temperature of $10.85 \pm 0.05^{\circ} \mathrm{C}$ can be obtained from this 2 -min section. On the fourth lowering $(176.5 \mathrm{~m})$ the penetration heat decayed normally for about $1 \mathrm{~min}$, then the probe was disturbed so that the temperature fell of rapidly. This time is just enough to permit an approximate extrapolation to equilibrium, giving an estimated in situ temperature of 11.92 $\pm 0.10^{\circ} \mathrm{C}$. The temperature decay for the first minute on this lowering matched closely that on the second lowering $(137 \mathrm{~m})$ so the decay curve for the latter can also be used to extimate equilibrium temperatures for this lowering. This method assumes that both the penetration heating and decay were the same. A similar equilibrium temperature was found this way.

The estimated equilibrium temperatures (Figure 8) have accuracies from 0.03 to $0.10^{\circ} \mathrm{C}$. Since the bumper subs were not working, the depths are only known to \pm 2 meters. The gradient between 137 and 148 meters, and its estimated accuracy is $0.047 \pm 0.007^{\circ} \mathrm{C} / \mathrm{m}$, between 148 and 176.5 meters it is $0.038 \pm 0.005^{\circ} \mathrm{C} / \mathrm{m}$ and the average gradient between 137 and 176.5 meters is 0.040 $\pm 0.003^{\circ} \mathrm{C} / \mathrm{m}$. The bottom-water temperature recorded was $3.70^{\circ} \mathrm{C}$ in agreement with the published value for 1300 meters water depth in this area (Wyrtki, 1971). The gradient from surface to 137 meters is then $0.0484^{\circ} \mathrm{C} / \mathrm{m}$.

The harmonic mean conductivity of seven samples in the temperature measurement interval between 137 and 176.5 meters is $2.80 \pm 0.33 \mathrm{mcal} / \mathrm{cm} \mathrm{sec}{ }^{\circ} \mathrm{C}$ for a heat flow of $1.12 \pm 0.22 \mu \mathrm{cal} / \mathrm{cm}^{2} \mathrm{sec}$. The mean of 11 samples from the surface to the upper temperature value is 2.73 $\pm 0.11 \mathrm{mcal} / \mathrm{cmsec}^{\circ} \mathrm{C}$ for a heat flow of $1.32 \pm 0.11$ $\mu \mathrm{cal} / \mathrm{cm}^{2} \mathrm{sec}$. This is $18 \%$ higher than the value from the deeper interval, but the difference is not significant. The accuracy of the lower interval gradient is particularly low. We estimate the best heat-flow value at this site to be $1.27 \pm 0.10 \mu \mathrm{cal} / \mathrm{cm}^{2} \mathrm{sec}$. 


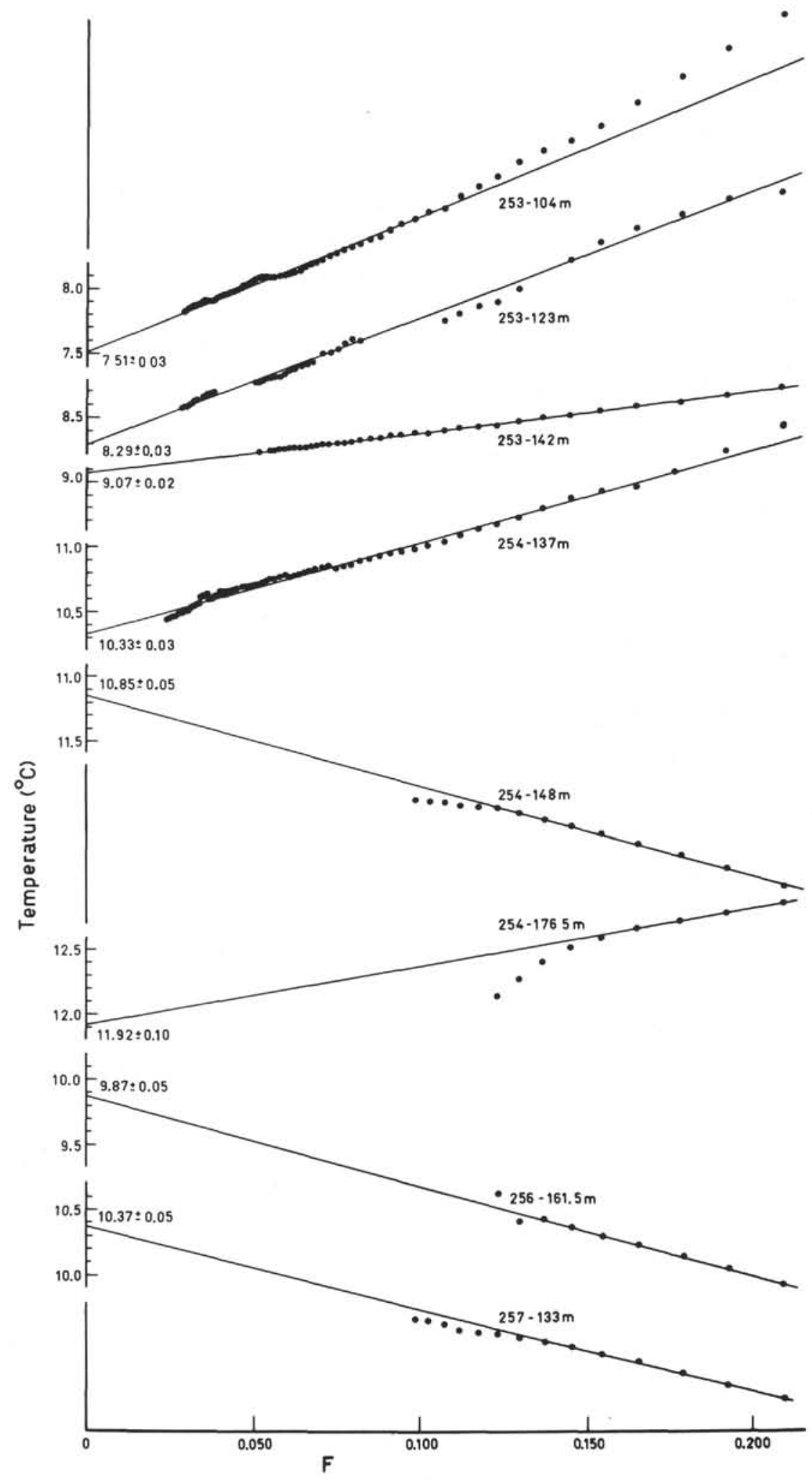

Figure 8. Extrapolation of recorded temperatures to equilibrium. 
TABLE 5

Summary of Leg 26 Heat-Flow Data

\begin{tabular}{|c|c|c|c|c|c|c|c|}
\hline Site & $\begin{array}{l}\text { Water } \\
\text { Depth } \\
(\mathrm{m})\end{array}$ & $\begin{array}{l}\text { Subbottom } \\
\text { Depth } \\
\text { (m) }\end{array}$ & $\begin{array}{l}\text { Temperature } \\
\left({ }^{\circ} \mathrm{C}\right)\end{array}$ & $\begin{array}{c}\text { Gradient } \\
\left({ }^{\circ} \mathrm{C} / \mathrm{m}\right) \times 10^{3}\end{array}$ & $\begin{array}{l}\text { Number of } \\
\text { Conductivity } \\
\text { Measurement }\end{array}$ & $\begin{array}{c}\text { Conductivity } \\
\left(\mathrm{mcal} / \mathrm{cm} \mathrm{sec}{ }^{\circ} \mathrm{C}\right)\end{array}$ & $\begin{array}{c}\text { Heat Flow } \\
\left(\mathrm{mcal} / \mathrm{cm}^{2} \mathrm{sec}\right)\end{array}$ \\
\hline 251 & 3489 & $\begin{array}{r}0.0 \\
87.5\end{array}$ & $\begin{array}{c}1.53 \pm 0.05 \\
(3.70 \text { minimum })\end{array}$ & (25) & 8 & $2.71 \pm 0.16$ & ( 0.7 minimum $)$ \\
\hline 253 & 1962 & $\begin{array}{r}0.0 \\
104.0 \\
123.0 \\
142.0\end{array}$ & $\left.\begin{array}{l}2.50 \pm 0.05 \\
7.51 \pm 0.03 \\
8.29 \pm 0.03 \\
9.07 \pm 0.02\end{array}\right\}$ & $\begin{array}{l}48.2 \pm 0.7 \\
41.1 \pm 3.2 \\
41.1 \pm 2.6\end{array}$ & $\begin{array}{l}4 \\
5\end{array}$ & $\begin{array}{l}2.85 \pm 0.07 \\
3.21 \pm 0.19\end{array}$ & $\begin{array}{l}1.37 \pm 0.08 \\
1.32 \pm 0.10\end{array}$ \\
\hline \multirow[t]{2}{*}{254} & 1253 & $\begin{array}{r}0.0 \\
119.5\end{array}$ & $\begin{array}{c}3.70 \pm 0.05 \\
(6.5 \text { minimum })\end{array}$ & $48.4 \pm 0.6$ & 11 & $2.73 \pm 0.11$ & $1.32 \pm 0.11$ \\
\hline & & $\begin{array}{l}137.0 \\
148.0 \\
176.5\end{array}$ & $\begin{array}{l}10.33 \pm 0.03 \\
10.85 \pm 0.05 \\
11.92 \pm 0.10\end{array}$ & \begin{tabular}{ll|l}
47 & \pm 7 \\
38 & \pm 5 & 40
\end{tabular} & 7 & $2.80 \pm 0.33$ & $1.12 \pm 0.22$ \\
\hline 256 & 5361 & $\begin{array}{r}0.0 \\
161.5\end{array}$ & $\begin{array}{l}1.14 \pm 0.05 \\
9.87 \pm 0.05\end{array}$ & $54.1 \pm 0.5$ & 6 & $2.03 \pm 0.15$ & $1.10 \pm 0.15$ \\
\hline 257 & 5278 & $\begin{array}{r}0.0 \\
133.0 \\
171.0\end{array}$ & $\begin{array}{c}1.06 \pm 0.02 \\
10.37 \pm 0.05 \\
(5.9 \text { minimum })\end{array}$ & $70.0 \pm 0.8$ & 10 & $1.97 \pm 0.12$ & $1.38 \pm 0.10$ \\
\hline
\end{tabular}

\section{Site 256}

Two downhole temperatures were attempted at Site 256 , both using the release latch and coring after temperature recording. On the first, at 161.5 meters, the sediment was too soft to support the bit. The bit was allowed to settle slowly 3 meters during 9 min of recording and then lowered another 4 meters quickly followed by $4 \mathrm{~min}$ more of recording. The bit was not rotated, but normally a core can be obtained in soft sediment just by lowering the drill string ("punch" coring). The instrument was recovered with the probe extender broken off. The latch had released, but there was no core. Apparently, during settling, the extender bent around the bit and was broken off when the instrument was lifted out with the core barrel. On the second lowering to 218.5

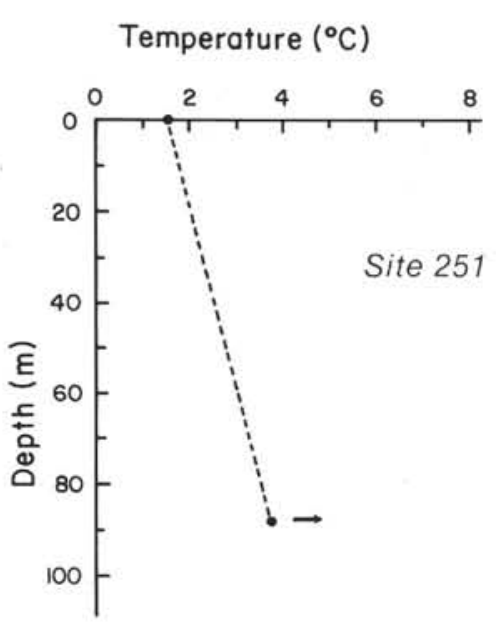

Thermal Conductivity (mcal/cm sec ${ }^{\circ} \mathrm{C}$ )

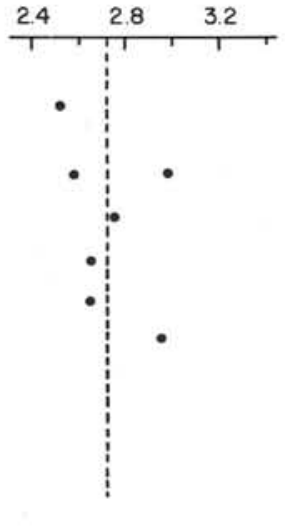

Figure 9. Temperature and conductivity with depth at Site 251. meters a recording package was lost. The bit was lifted a short distance off the bottom after the temperature recording and then lowered and rotated for coring. The sediment was quite hard. The extra 4000 to 8000 pounds lift required to free the core barrel pulled the instrument through the two core catchers. Again the extender must have wrapped around the bit. Rotation during coring may have thoroughly entangled it.

Temperatures recorded on the first lowering showed a sharp temperature increase on penetration, but the
Temperature $\left({ }^{\circ} \mathrm{C}\right)$

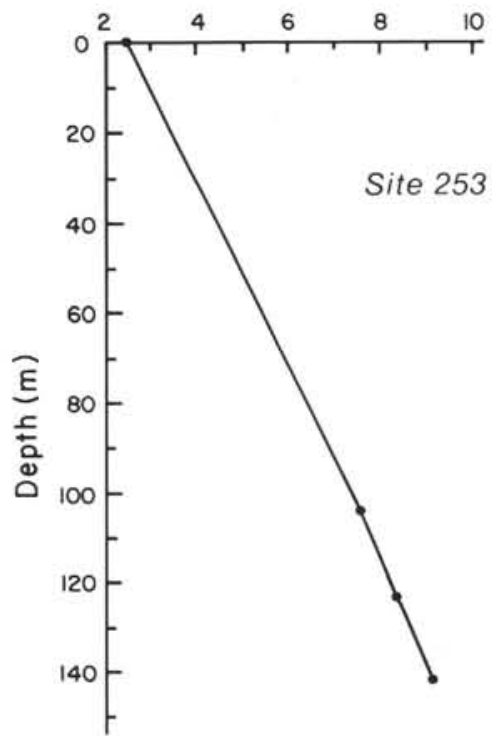

Thermal Conductivity (mcal/cm sec ${ }^{\circ} \mathrm{C}$ )

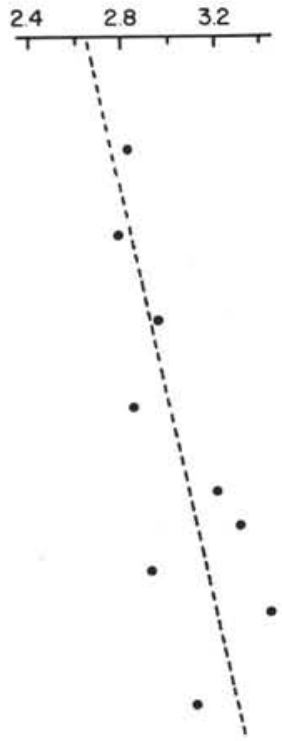

Figure 10. Temperature and conductivity with depth at Site 253. 


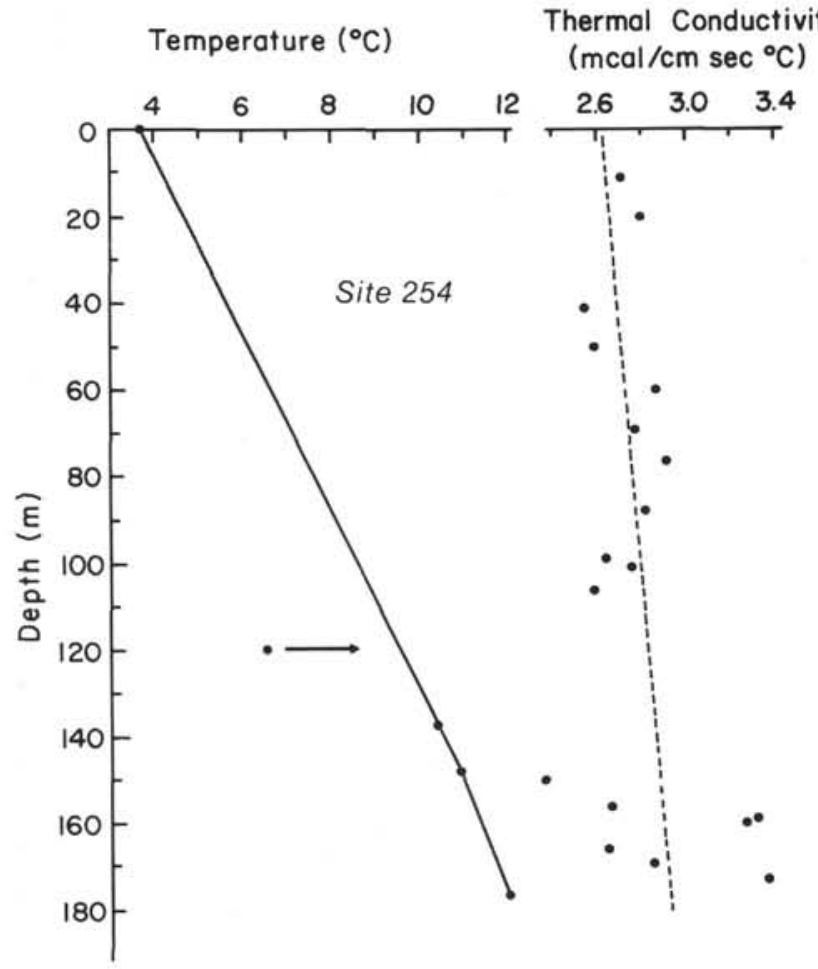

Figure 11. Temperature and conductivity with depth at Site 254.

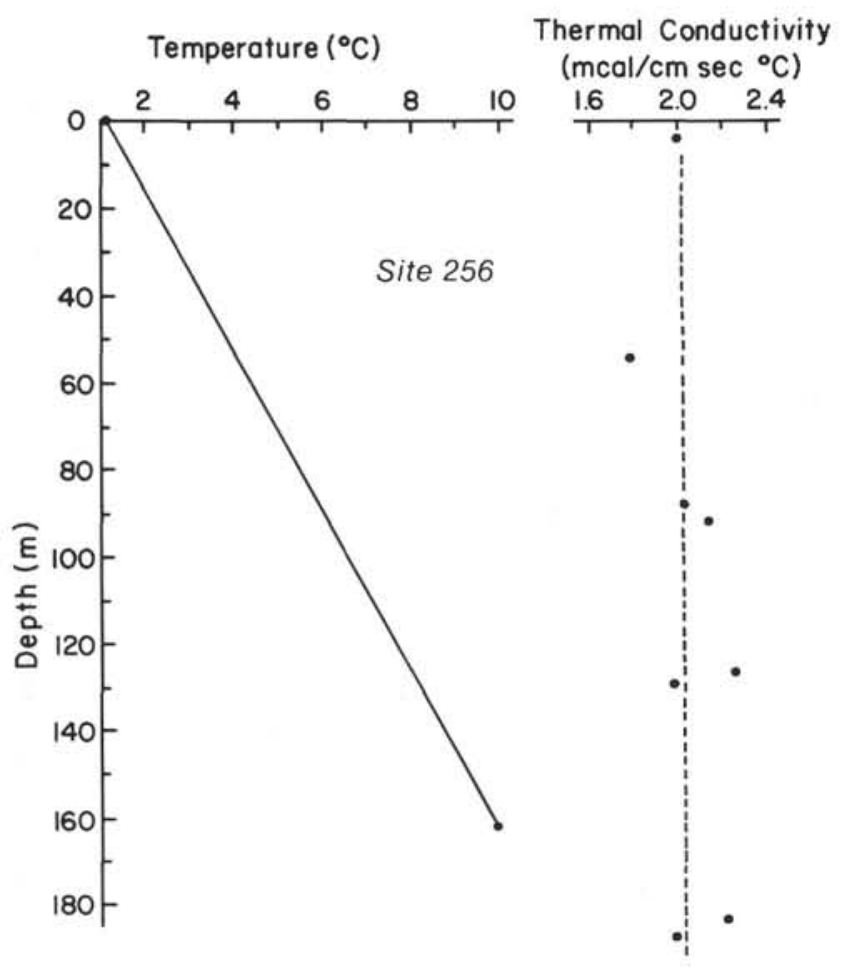

Figure 12. Temperature and conductivity with depth at Site 256.

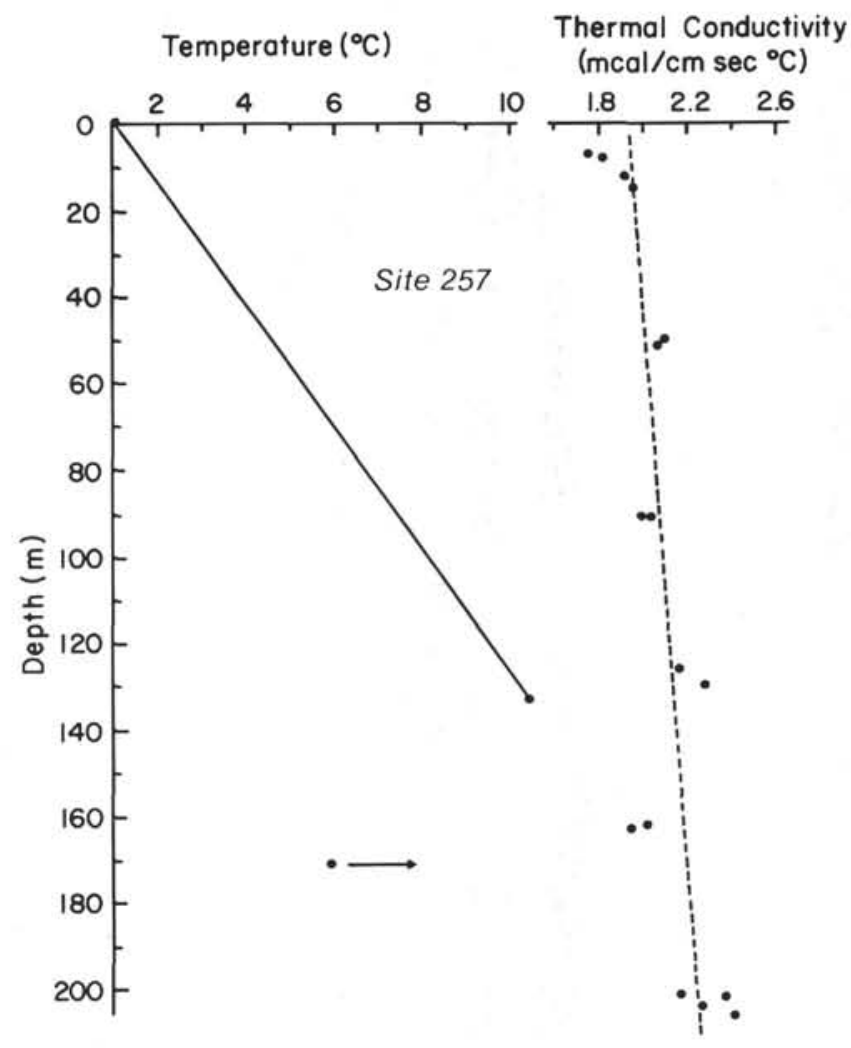

Figure 13. Temperature and conductivity with depth at Site 257.

temperature then decreased very rapidly suggesting that the probe had been immediately pulled out. The temperatures were low and irregular until the bit was rapidly lowered 4 meters at which time they increased and followed the characteristic curve for the approach to equilibrium for $2 \mathrm{~min}$. The probe apparently penetrated to undisturbed sediments after the 4 meters of extra lowering. Extrapolating the $2 \mathrm{~min}$ of undisturbed record gives an equilibrium temperature of 9.87 $\pm 0.05^{\circ} \mathrm{C}$. A very rough estimate obtained from the maximum temperature, which is usually $1-3^{\circ} \mathrm{C}$ above equilibrium, is $8.5-10.5^{\circ} \mathrm{C}$ which substantiates the above value. The bottom-water temperature recorded was $1.14^{\circ} \mathrm{C} \pm 0.05$, giving a gradient from the sea floor to 161.5 meters of $0.0541 \pm 0.0005^{\circ} \mathrm{C} / \mathrm{m}$. The harmonic mean thermal conductivity of six samples between the surface and 161.5 meters was $2.03 \pm 0.15 \mathrm{mcal} / \mathrm{cmsec}$ ${ }^{\circ} \mathrm{C}$, giving a heat flow of $1.10 \pm 0.15 \mu \mathrm{cal} / \mathrm{cm}^{2} \mathrm{sec}$.

Site 257

Three measurements were attempted at Site 257. The first at 133.0 meters gave a good temperature versus time record. The frictional heating pulse was small so he approach to equilibrium was a temperature increase. The record was undisturbed for about $3 \mathrm{~min}$ and gives an extrapolated temperature of $10.37 \pm 0.05^{\circ} \mathrm{C}$. On the second lowering to 171 meters the thermistor probe was bent at right angles to the extender and filled with water. Temperatures were still recorded so the leak must have only occurred with release of pressure near the surface. 
However, there was only a small change in temperature to $5.9^{\circ} \mathrm{C}$ when the bit and instrument were lowered into the bottom. The core barrel may not have seated in the drill collar and the probe therefore may not have extended through he bit. On the third lowering, the extender was broken off and no useful temperatures were obtained. We conclude that on each of these lowerings, the extender was being deflected by the partly open bottom "flapper" valve onto the flat surface at the back of the bit. Stronger valve springs than previously used had been installed for this hole. Bottom-water temperatures were well recorded on the first two lowerings at $1.06 \pm 0.02^{\circ} \mathrm{C}$. With the one good temperature a gradient of $0.0700^{\circ} \mathrm{C} / \mathrm{m} \pm 0.0008$ is calculated from the sea floor to 133 meters.

Thermal conductivity increases smoothly from about 1.9 near the surface to $2.3 \mathrm{mcal} / \mathrm{cm} \mathrm{sec}{ }^{\circ} \mathrm{C}$ near the basement. The harmonic mean of 10 samples between the surface and 133 meters is $1.97 \pm 0.12 \mathrm{mcal} / \mathrm{cm} \mathrm{sec}$ ${ }^{\circ} \mathrm{C}$, giving a heat flow of $1.38 \pm 0.10 \mu \mathrm{cal} / \mathrm{cm}^{2} \mathrm{sec}$.

\section{CONCLUSIONS}

Four reliable heat measurments have been obtained on Leg 26 with accuracies from $5 \%$ to $15 \%$. The values range from 1.1 to $1.4 \mu \mathrm{cal} / \mathrm{cm} \mathrm{sec}$. The closely spaced temperature points at Site 253 provide a good confirmation of the reproducibility of measured temperatures using the downhole recorder in DSDP holes. A number of temperature-versus-time records showing clearly the decay of the penetration heating were obtained for the first time on this leg. These curves permitted the use of heat-conduction theory to extrapolate the observed data to equilibrium in situ temperature. Relative accuracies as good as $\pm 0.03^{\circ} \mathrm{C}$ were achieved on several lowerings. The main limits to accuracy are (1) inadequate penetration of the probe and (2) small movements of the probe during the recording period.

Heat flux is constant with depth to within the measurement accuracy in the two sites with four temperature points.

The Leg 26 heat-flow results are compared with nearby shallow ocean probe results in Figure 14 (compilation by J. G. Sclater; see also McKenzie and Sclater [1971]; unpublished data from Vema 24 cruise provided by M. G. Langseth). There is general agreement although the scatter is quite large. The low value at Site 251 is in agreement with a very close ocean-probe site which is surprising since we believe the Site 251 value of $0.7 \mu \mathrm{cal} / \mathrm{cm}^{2} \mathrm{sec}$ is too low.

The fit of the Leg 26 heat-flow values to the theoretical age versus heat-flow relation is shown in Figure 15 (Model 2 of Sclater and Francheteau, 1970). There is hardly a significant trend in our data which suggests that the disagreement between theoretical and shallow probe measured values (see McKenzie and Sclater, 1971) may not arise only from superficial processes.

\section{ACKNOWLEDGMENTS}

Helpful comments on the manuscript were obtained from Drs. P. H. Reynolds and J. Wright.

\section{REFERENCES}

Anderson, R. N., 1972. Petrologic significance of low heat flow on the flanks of slow-spreading mid-ocean ridges: Geol. Soc. Am. Bull., v. 83, p. 2947.

Birch, F. 1950. Flow of heat in the Front Range, Colorado: Geol. Soc. Am. Bull., v. 61, p. 567.

Bullard, E. C., 1954. The flow of heat through the floor of the Atlantic Ocean: Roy. Soc. London, Phil. Trans. Ser. A, v. 222 , p. 408.

1963. The flow of heat through the floor of the ocean: In Hill, M. N. (Ed.), The sea, vol. 3: New York (WileyInterscience), p. 218.

Erickson, A. J., 1973. Initial report on downhole temperature and shipboard thermal conductivity measurements, Leg 19, Deep Sea Drilling Project. In Creager, J. S., Scholl, D. W., et al., Initial Reports of the Deep Sea Drilling Project, Volume 19: Washington (U.S. Government Printing Office), p. 643.

Hamilton, E. L., 1959. Thickness and consolidation of deep sea sediments: Geol. Soc. Am. Bull., v. 70, p. 1399.

Hyndman, R. D. and Jessop, A. M., 1971. The mid-Atlantic ridge near $45^{\circ} \mathrm{N}$. XV. Thermal conductivity of dredge and drill core samples: Canadian J. Earth Sci., v. 8, p. 391.

Hyndman, R. D. and Rankin, D. S., 1972. The mid-Atlantic ridge near $45^{\circ} \mathrm{N}$. XVIII. Heat flow measurements: Canadian J. Earth Sci., v. 9, p. 664.

Jaeger, J. C., 1956. Numerical values for the temperature in radial heat flow: J. Math. Phys., v. 34, p. 316.

Langseth, M. G. and Von Herzen, R. P., 1971. Heat flow through the floor of the world oceans. In Maxwell, A. E. (Ed.), The sea, vol. 4, Pt. 1: New York (Wiley-Interscience), p. 299.

Lister, C. R. B., 1972. On the thermal balance of a mid-ocean ridge: Geophys. J., v. 26, p. 515.

McKenzie, D. P., 1967. Some remarks on heat flow and gravity anomalies: J. Geophys. Res., v. 72, p. 6261.

1969. Speculations on the consequences and causes of plate motions: Geophys. J., v. 18, p. 1.

McKenzie, D. P. and Sclater, J. G., 1971. The evolution of the Indian Ocean since the Late Cretaceous: Geophys. J., v. 24, p. 437.

Ratcliffe, E. H., 1959. Thermal conductivities of fused and crystalline quartz: British J. Appl. Phys., v. 10, p. 22.

1960. The thermal conductivities of ocean sediments: J. Geophys. Res., v. 65, p. 1535.

Revelle, R. and Maxwell, A. E., 1952. Heat flow through the floor of the eastern North Pacific Ocean: Nature, v. 170, p. 199.

Sclater, J. G. and Francheteau, J., 1970. The implications of terrestrial heat flow observations on current tectonic and geochemical models of the crust and upper mantle of the earth: Geophys. J., v. 20 , p. 509.

Von Herzen, R. P. and Maxwell, A. E., 1959. The measurement of thermal conductivity of deep-sea sediments by a needle probe method: J. Geophys. Res., v. 64, p. 1557.

Von Herzen, R. P. and S. Uyeda, 1963. Heat flow through the eastern Pacific Ocean floor: J. Geophys. Res., v. 68, p. 4219.

1964. Measurements of heat flow at the preliminary Mohole site off Mexico: J. Geophys. Res., v. 69, p. 741.

Von Herzen, R. P. and Uyeda, S. 1963. Heat flow through the eastern Pacific Ocean floor: J. Geophys. Res., v. 68, p. 4219.

Wytki, K., 1971. Oceanographic Atlas of the International Indian Ocean Expedition: Washington, (U.S. Government Printing Office). 

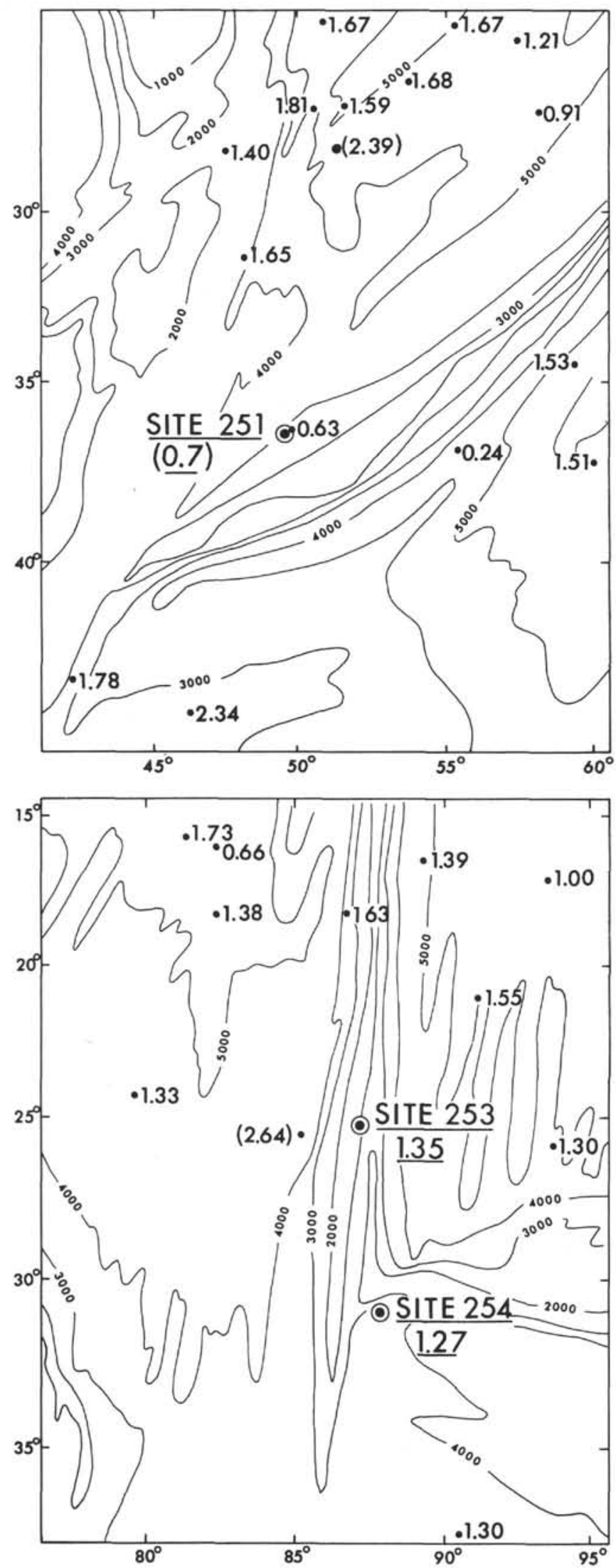

Figure 14. Comparison of Leg 26 and nearby shallow ocean probe data. Heat-flow values are underlined and are in $10^{-6} \mathrm{cal} / \mathrm{cm}^{2} \mathrm{sec}$. Low-accuracy values are in parentheses.

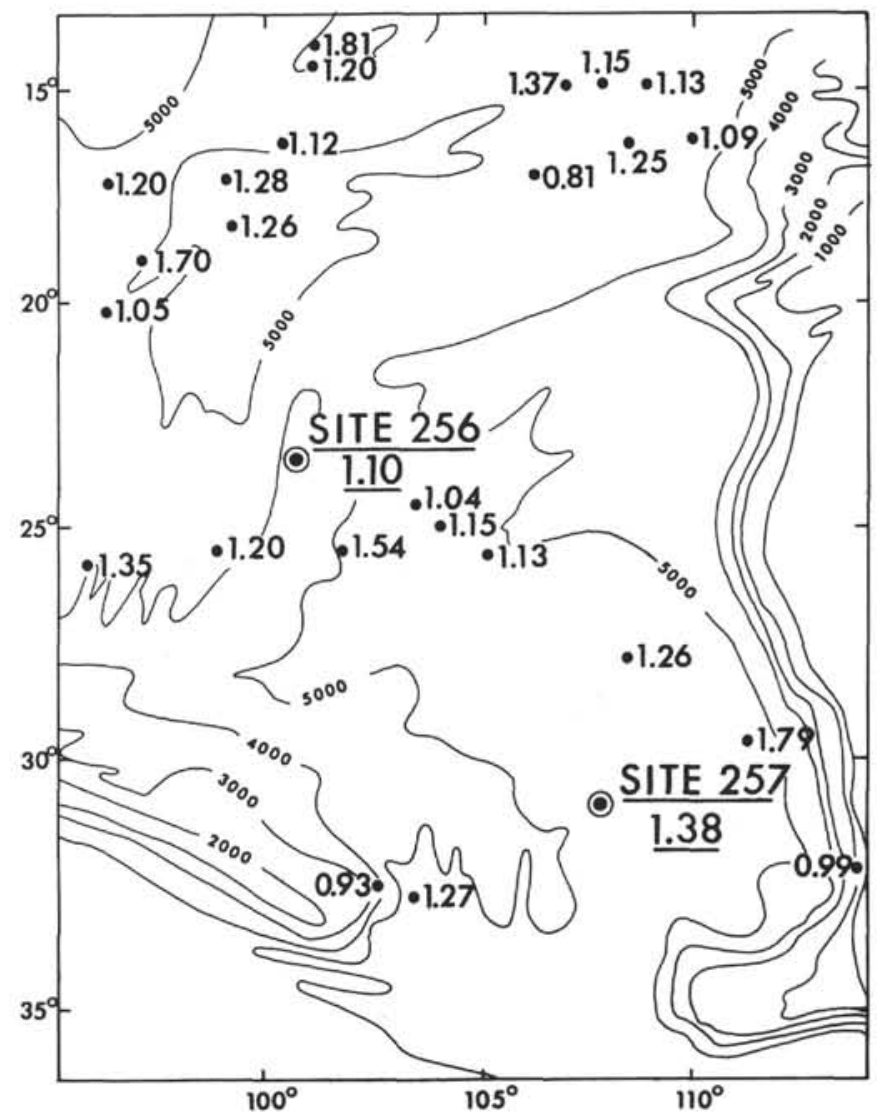

Figure 14. (Continued).

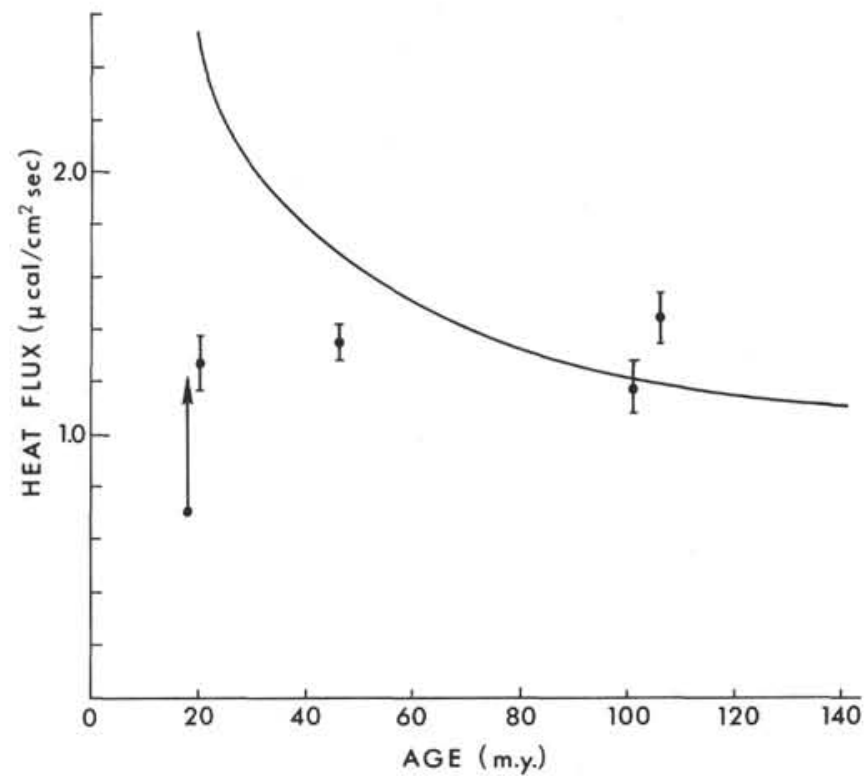

Figure 15. Theoretical and observed heat-flow relation versus age. 